\title{
Environmental effects on photosynthetic capacity of bean genotypes
}

\author{
Rafael Vasconcelos Ribeiro(1), Mauro Guida dos Santos(1), Gustavo Maia Souza(1), Eduardo Caruso Machado(2), \\ Ricardo Ferraz de Oliveira ${ }^{(1)}$, Luiz Roberto Angelocci ${ }^{(3)}$ and Carlos Pimentel( ${ }^{(4)}$
}

\begin{abstract}
(1)Escola Superior de Agricultura Luiz de Queiroz (Esalq), Dep. de Ciências Biológicas, Caixa Postal 9, CEP 13418-900 Piracicaba, SP, Brazil. E-mail: rvribeir@esalq.usp.br, mgsantos@esalq.usp.br, gumaia@universiabrasil.net, rfolivei@esalq.usp.br(2)Instituto Agronômico, Centro de Pesquisa e Desenvolvimento em Ecofisiologia e Biofísica, Caixa Postal 28, CEP 13001-970 Campinas, SP, Brazil. E-mail: caruso@iac.sp.gov.br (3)Esalq, Dep. de Ciências Exatas. E-mail: Irangelo@esalq.usp.br (4)Universidade Federal Rural do Rio de Janeiro, Instituto de Agronomia, Dep. de Fitotecnia, CEP 28851-970 Seropédica, RJ, Brazil. E-mail: greenman@amcham.com.br
\end{abstract}

\begin{abstract}
Photosynthetic responses to daily environmental changes were studied in bean (Phaseolus vulgaris L.) genotypes 'Carioca', 'Ouro Negro', and Guarumbé. Light response curves of $\mathrm{CO}_{2}$ assimilation and stomatal conductance $\left(\mathrm{g}_{\mathrm{s}}\right)$ were also evaluated under controlled (optimum) environmental condition. Under this condition, $\mathrm{CO}_{2}$ assimilation of 'Carioca' was not saturated at 2,000 $\mu \mathrm{mol} \mathrm{m}^{-2} \mathrm{~s}^{-1}$, whereas Guarumbé and 'Ouro Negro' exhibited different levels of light saturation. All genotypes showed dynamic photoinhibition and reversible increase in the minimum chlorophyll fluorescence yield under natural condition, as well as lower photosynthetic capacity when compared with optimum environmental condition. Since differences in $\mathrm{g}_{\mathrm{s}}$ were not observed between natural and controlled conditions for Guarumbé and 'Ouro Negro', the lower photosynthetic capacity of these genotypes under natural condition seems to be caused by high temperature effects on biochemical reactions, as suggested by increased alternative electron sinks. The highest $g_{s}$ values of 'Carioca' were observed at controlled condition, providing evidences that reduction of photosynthetic capacity at natural condition was due to low $\mathrm{g}_{\mathrm{s}}$ in addition to the high temperature effects on the photosynthetic apparatus. 'Carioca' exhibited the highest photosynthetic rates under optimum environmental condition, and was more affected by daily changes of air temperature and leaf-to-air vapor pressure difference.
\end{abstract}

Index terms: Phaseolus vulgaris, chlorophyll fluorescence, gas exchange, photosynthesis.

\section{Efeitos ambientais na capacidade fotossintética de genótipos de feijoeiro}

Resumo - Foram avaliadas as respostas fotossintéticas às variações diárias do ambiente nos genótipos de feijoeiro (Phaseolus vulgaris L.) 'Carioca', 'Ouro Negro' e Guarumbé. Curvas de resposta da assimilação de $\mathrm{CO}_{2}$ e condutância estomática $\left(\mathrm{g}_{\mathrm{s}}\right)$ à luz foram realizadas em condição ambiental controlada (ótima). Nessa condição a assimilação de $\mathrm{CO}_{2}$ de 'Carioca' não foi saturada mesmo a $2.000 \mu \mathrm{mol} \mathrm{m}^{-2} \mathrm{~s}^{-1}$, enquanto Guarumbé e 'Ouro Negro’ apresentaram diferentes níveis de saturação lumínica. Os genótipos mostraram fotoinibição dinâmica e aumento reversível da fluorescência mínima da clorofila em condição natural, assim como menor capacidade fotosintética quando comparada à sob condição controlada. Uma vez que Guarumbé e 'Ouro Negro' apresentaram valores similares de $\mathrm{g}_{\mathrm{s}}$ em ambas condições ambientais, a menor capacidade fotossintética desses genótipos sob condição natural parece ser causada pelos efeitos da alta temperatura nas reações bioquímicas, como sugerido pelo aumento dos drenos alternativos de elétrons. Os maiores valores de $\mathrm{g}_{\mathrm{s}} \mathrm{em}$ 'Carioca' foram observados em condição controlada, podendo a redução da capacidade fotossintética em condição natural ser atribuída aos baixos valores de $\mathrm{g}_{\mathrm{s}} \mathrm{em}$ adição aos efeitos da alta temperatura no aparato fotossintético. 'Carioca' exibiu as maiores taxas fotossintéticas em condições ambientais ótimas, sendo mais afetado pelas mudanças diárias de temperatura do ar e diferença de pressão de vapor folha-ar.

Termos para indexação: Phaseolus vulgaris, fluorescência de clorofila, fotossíntese, trocas gasosas.

\section{Introduction}

Among crops used in human alimentation, common bean has a great importance as a source of protein and energy (Dourado Neto \& Fancelli, 2000). Due to the large cultivated area, bean plants are submitted to different environments with distinct air humidity, temperature, and irradiance levels (Singh, 1989), which affect the plant growth and productivity (Lopes et al., 1986). Photosynthesis is the main process responsible 
for dry matter accumulation and consequently affects plant development and growth, being strongly regulated by the environment (McCree, 1986).

Stomatal conductance controls the photosynthesis (Farquhar \& Sharkey, 1982; Jones, 1998), and stomatal behavior is influenced by both external and internal stimuli (Nobel, 1999). So, it could be expected negative stomatal effects on photosynthetic process in some conditions, when there is low air relative humidity or high air temperature. High temperature induces direct and indirect changes on bean photosynthesis, affecting directly the biochemical reactions (Pastenes \& Horton, 1996a, 1996b) and causing stomatal closure (Comstock \& Ehleringer, 1993) due to the increased air vapor pressure deficit. Both effects are always present in nature, where it is difficult to ascribe which one has more influence on leaf gas exchange.

The photochemical activity is also affected by environmental stresses (Van Kooten \& Snel, 1990; Maxwell \& Johnson, 2000), such as high temperature (Yamane et al., 1997; Costa et al., 2002). Photochemical reactions are linked to the $\mathrm{CO}_{2}$ fixation process by supplying ATP and NADPH, and are also regulated by alternative electron sinks, such as photorespiration, Mehler reaction and nitrogen reduction (Champigny, 1995; Cornic \& Fresneau, 2002; Noctor et al., 2002). In addition to the effect of high temperature (Pastenes \& Horton, 1996b; Yamane et al., 1997; Pastenes \& Horton, 1999), the photochemical apparatus may also be influenced by high light intensity (Long et al., 1994; Osmond, 1994; Critchley, 1998), which frequently occurs around noon when air temperature and vapor pressure deficit are elevated. Concerning the effects of elevated air temperature in bean plants, Pastenes \& Horton (1996b) and Costa et al. (2002) observed that the susceptibility of photosynthetic apparatus depends on studied genotype. Therefore, bean cultivars show different physiological responses when submitted to the same changes in air temperature and vapor pressure deficit. In fact, these responses permit genotypes to avoid or tolerate high temperature effects, allowing plants to maintain adequate or reasonable photosynthetic rates (Pastenes \& Horton, 1996a, 1996b, 1999; Costa et al., 2002).

Daily environmental changes of air temperature, vapor pressure deficit, and irradiance may occur simultaneously, affecting plant species in different degrees. Thus, the overall effect is not a sum of isolate influences of each environmental constraint, but rather a synergetic effect. Regardless the water deficit effects on bean physiology (Pimentel et al., 1999a, 1999b; Souza et al., 2003), studies involving the impacts of natural environmental fluctuation on the physiology of different bean genotypes have not been reported. Greater knowledge on how plants respond to natural environmental changes and how they are affected may improve crop management and show some guidelines for bean breeding programs in regions with specific environmental characteristics.

The objective of this work was to evaluate the effects of daily environmental changes on photosynthetic capacity of bean (Phaseolus vulgaris L.) genotypes 'Carioca', 'Ouro Negro' and the landrace Guarumbé.

\section{Material and Methods}

Five bean seeds (Phaseolus vulgaris L.) of genotypes 'Carioca', 'Ouro Negro', and Guarumbé were sown in $10 \mathrm{~L}$ pots, containing the substrate Plantmax. After seed germination, two plants were kept per pot. Seedlings were grown under greenhouse condition, where there was maximal irradiance intensity at about $1,800 \mu \mathrm{mol} \mathrm{m}{ }^{-2} \mathrm{~s}^{-1}$, air temperature from $44^{\circ} \mathrm{C}$ to $18^{\circ} \mathrm{C}$, and RH between 30 and $100 \%$. A nutrient solution (McCree, 1986) was applied at sowing and 15 days after seedling emergence (DAE) to ensure that no nutritional deficiency would occur. Plants were watered daily (except during fertirrigation).

Measurements of leaf gas exchange were taken in completely expanded and exposed leaves at 25 DAE, using the LICOR LI-6400 infrared gas analyzer. The $\mathrm{CO}_{2}$ and water vapor fluxes were measured and the $\mathrm{CO}_{2}$ assimilation (A) and transpiration (E) rates, stomatal conductance $\left(\mathrm{g}_{\mathrm{s}}\right)$, and intercellular $\mathrm{CO}_{2}$ concentration (Ci) were calculated by the LI-6400 data analysis program according to Von Caemmerer \& Farquhar (1981).

Chlorophyll a fluorescence was measured with the Hansatech FMS1 modulated fluorometer, wherein the maximal $\left(\mathrm{F}_{\mathrm{m}}\right)$ and minimum $\left(\mathrm{F}_{\mathrm{o}}\right)$ fluorescence yields were obtained in dark-adapted (30 min) leaves, and steady-state $\left(F_{\mathrm{s}}\right)$ and maximal $\left(\mathrm{F}_{\mathrm{m}}{ }^{\prime}\right)$ fluorescence yields were measured in light-adapted leaves (Van Kooten \& Snel, 1990). Thus, variable fluorescence yield was determined in dark-adapted $\left(\mathrm{F}_{\mathrm{v}}=\mathrm{F}_{\mathrm{m}}-\mathrm{F}_{\mathrm{o}}\right)$ and in lightadapted $\left(\Delta \mathrm{F}=\mathrm{F}_{\mathrm{m}}{ }^{\prime}-\mathrm{F}_{\mathrm{s}}\right)$ states. $\mathrm{F}_{\mathrm{o}}{ }^{\prime}$ is the minimum 
fluorescence yield after photosystem I excitation by farred light. The following parameters were calculated: the potential $\left(\mathrm{F}_{\mathrm{v}} / \mathrm{F}_{\mathrm{m}}\right)$ and effective $\left(\Delta \mathrm{F} / \mathrm{F}_{\mathrm{m}}{ }^{\prime}\right)$ quantum efficiency of photosystem II (PSII), and the apparent electron transport rate $[\mathrm{ETR}=(\mathrm{PPFD} \times \Delta \mathrm{F} /$ $\left.\left.F_{m}{ }^{\prime} \times 0.5 \times 0.84\right)\right]($ Schreiber et al., 1994). For the calculation of ETR, the fraction of excitation energy distributed to PSII used was 0.5 , and the fractional photosynthetic photon flux density (PPFD) absorption used was 0.84 (Demmig \& Björkman, 1987). The alternative electron sinks (AES) were estimated as the relation between $\Delta \mathrm{F} / \mathrm{F}_{\mathrm{m}}$ ' and the quantum efficiency of $\mathrm{CO}_{2}$ assimilation $\left[\Phi \mathrm{CO}_{2}=\mathrm{A} /(\mathrm{PPFD} \times 0.84)\right]$ (adapted from Edwards \& Baker, 1993).

Seven days after transferring plants from greenhouse to full sunlight condition (open area in Piracicaba, SP, Brazil, $22^{\circ} 42^{\prime} \mathrm{S}, 47^{\circ} 30^{\prime} \mathrm{W}, 576 \mathrm{~m}$ of altitude) characteristic of summer season, the measurements of leaf gas exchange and chlorophyll a fluorescence were taken in the same leaf, in intervals of approximately 1.5 hours between 6 am and $6 \mathrm{pm}$. The leaf water potential $\left(\psi_{\mathrm{w}}\right)$ was measured by the psychometric method, operating in hygrometric dew point mode, with the Wescor HR-33T microvoltmeter and Wescor C-52 sample chambers at pre-dawn and at 1:30 pm. Environmental variables were monitored by the LI-6400, with PPFD, air temperature $\left(\mathrm{T}_{\text {air }}\right)$ and leaf-to-air vapor pressure difference $\left(\mathrm{VPD}_{\text {leaf-air }}\right)$ recorded at same time of the physiological measurements.

Photosynthetic capacity (PC) under optimum environmental condition was determined through light response curves of $\mathrm{A}$ and $\mathrm{g}_{\mathrm{s}}$ at controlled condition, with leaf temperature of $25^{\circ} \mathrm{C}$ and air vapor pressure deficit (VPD) around $1.0 \mathrm{kPa}$. Leaf temperature was controlled by the LI-6400 and VPD by the LICOR LI-610 dew point generator attached to the LI-6400. Both values of leaf temperature and VPD are considered to be optimum to the photosynthetic activity and to prevent stomatal closure respectively (Jones, 1971; Comstock \& Ehleringer, 1993). Light response curves of A and $\mathrm{g}_{\mathrm{s}}$ were obtained varying PPFD from 2,000 to $0 \mu \mathrm{mol} \mathrm{m} \mathrm{m}^{-2} \mathrm{~s}^{-1}$.

The experiment was arranged in a completely randomized block design, with three and six replications, at controlled and natural conditions, respectively, sampled in different plants. Data were subjected to analysis of variance (ANOVA) and the mean values were compared by Tukey's test at the 0.05 probability level.

\section{Results and Discussion}

The highest values of $\mathrm{T}_{\text {air }}, \mathrm{VPD}_{\text {leaf-air }}$ and PPFD were observed in the afternoon $(1: 17 \mathrm{pm})$, with values of $\mathrm{T}_{\text {air }}$ higher than $38^{\circ} \mathrm{C}, \mathrm{VPD}_{\text {leaf-air }}$ of $3.7 \mathrm{kPa}$ and PPFD around $2,000 \mu \mathrm{mol} \mathrm{m}^{-2} \mathrm{~s}^{-1}$ (Figure 1).

Daily course of $\mathrm{CO}_{2}$ assimilation (A) was similar for all evaluated genotypes (Figure 2 ). In early morning, the sharp increase in photosynthetic photon flux density (PPFD) seems to be the main cause of A increases. Considering the highest A values, no statistical difference was found between bean genotypes under natural condition. Maximal A rates were reached around 8:45 am and maintained until 11:45 am when reductions in stomatal conductance $\left(\mathrm{g}_{\mathrm{s}}\right)$ were caused by increasing leaf-to-air vapor pressure difference (VPD leaf-air $_{\text {) }}$ (Figure 2). Low $\mathrm{g}_{\mathrm{s}}$ is known to cause decrease in A by reducing the $\mathrm{CO}_{2}$ available, which may be indicated by decreased intercellular $\mathrm{CO}_{2}$ concentration (Ci) values (Jones, 1998; Nobel, 1999). Nevertheless, relatively stable Ci values from 8:35 am to 3:09 pm suggested that stomatal closure was not the main cause of reductions in $\mathrm{A}$ in that time (Figure 2). Hence, it could be inferred that the high air temperature (higher than $36^{\circ} \mathrm{C}$ ) caused increase in photorespiration and consequent reduction in the photosynthetic activity, as indicated by increased alternative electron sinks (AES) (Figure 3).

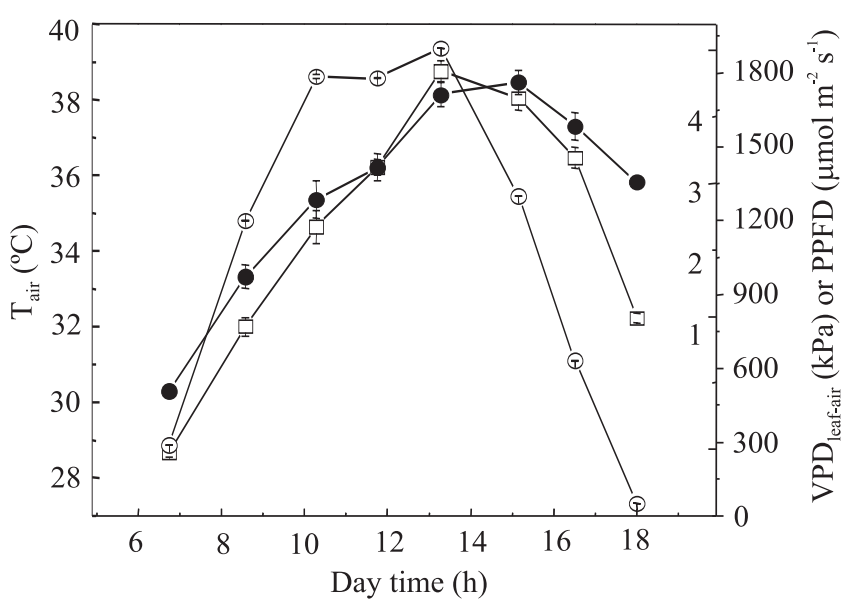

Figure 1. Daily courses of air temperature $\left(\mathrm{T}_{\text {air }}: \square\right)$, leaf-to-air vapor pressure difference $\left(\mathrm{VPD}_{\text {leaf-air }}: \bullet\right)$ and photosynthetic photon flux density (PPFD: O) at full sunlight condition in summer season of Piracicaba, SP, Brazil. Each point represents the mean \pm standard error of 18 replications. 
Stomata showed a slight opening tendency until 11:45 am, when decreases in $\mathrm{g}_{\mathrm{s}}$ were likely due to high transpiration (E) values (Figure 2). Increases in $\mathrm{E}$ were caused by an elevation of $\mathrm{VPD}_{\text {leaf-air, }}$ which induced reductions in $\psi_{\mathrm{w}}$ (Table 1). Since similar $\mathrm{g}_{\mathrm{s}}$ values were observed during morning, changes in E values suggest that stomatal aperture was more than sufficient to support maximal E values since early hours of morning.

The photochemical apparatus of bean genotypes was also affected by environmental conditions (Figure 4). High PPFD levels caused photoinhibition in all genotypes. Photoinhibition is recognized by decreases in the quantum efficiency of PSII and indicated by $\mathrm{F}_{\mathrm{v}} / \mathrm{F}_{\mathrm{m}}$ values below to 0.725 (Critchley, 1998), being caused by excessive light energy (Long et al., 1994).

The lowest $\mathrm{F}_{\mathrm{v}} / \mathrm{F}_{\mathrm{m}}$ values were observed at 11:45 am in all genotypes, but different photoinhibition recovery capacities were observed among 'Carioca', Guarumbé and 'Ouro Negro' (Figure 4). Guarumbé was most affected by excessive light energy, being the last

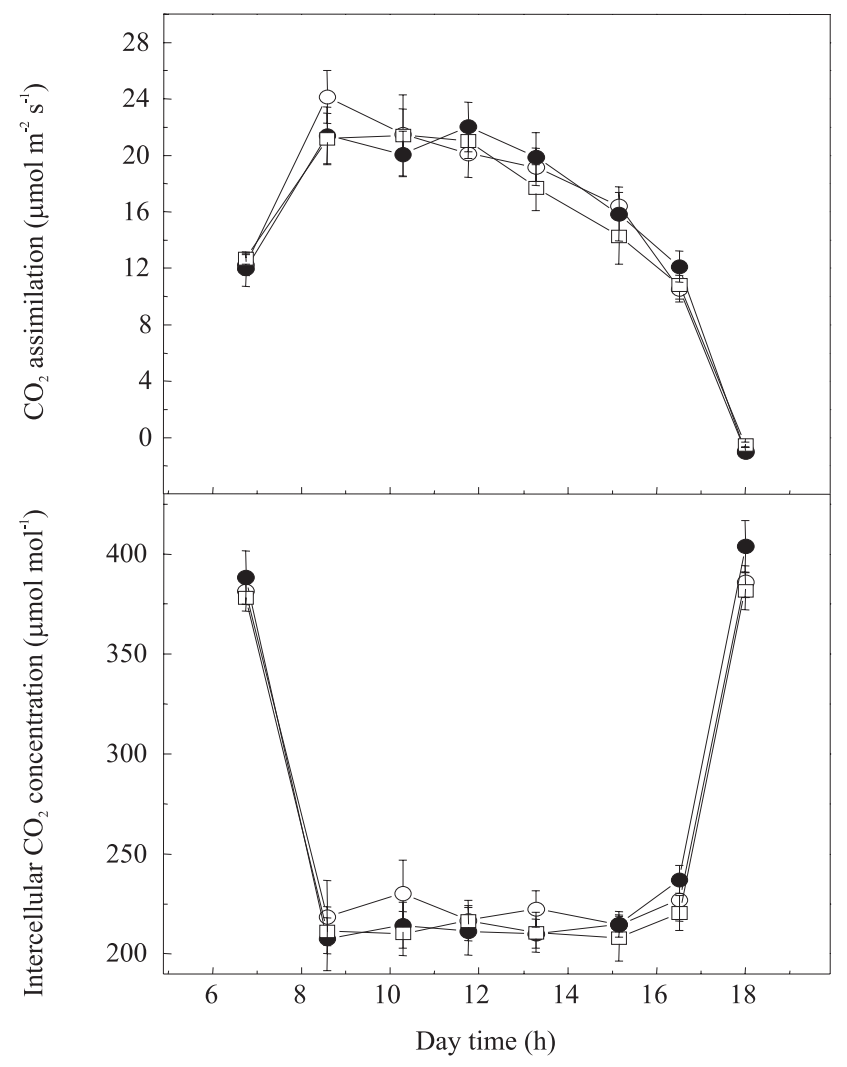

genotype to initiate the photoinhibition recovery (at 4:30 pm), whereas 'Ouro Negro' and 'Carioca' exhibited $\mathrm{F}_{\mathrm{v}} / \mathrm{F}_{\mathrm{m}}$ recovery from 11:45 am and 1:17 pm, respectively.

The photoinhibition mechanism could have a character of photoprotection or represent damaging in PSII reaction centers (Osmond, 1994). The former is associated to an avoidance of over-excitation of the PSII reaction center by decreased energy absorption or by increased thermal dissipation of excitation energy via xanthophyll cycle, and the later is related to a cycle of PSII reaction center inactivation and repair (Demmig-Adams III \& Adams III, 1992; Long et al., 1994; Osmond, 1994; Critchley, 1998). In this study, all genotypes exhibited dynamic photoinhibition, i.e., a photoprotective mechanism (Osmond, 1994).

Increases in PPFD also caused reductions in $\Delta \mathrm{F} / \mathrm{F}_{\mathrm{m}}$, when the lowest values were observed after midday in all genotypes (Figure 4). As expected, an inverse pattern was observed between apparent electron transport rate

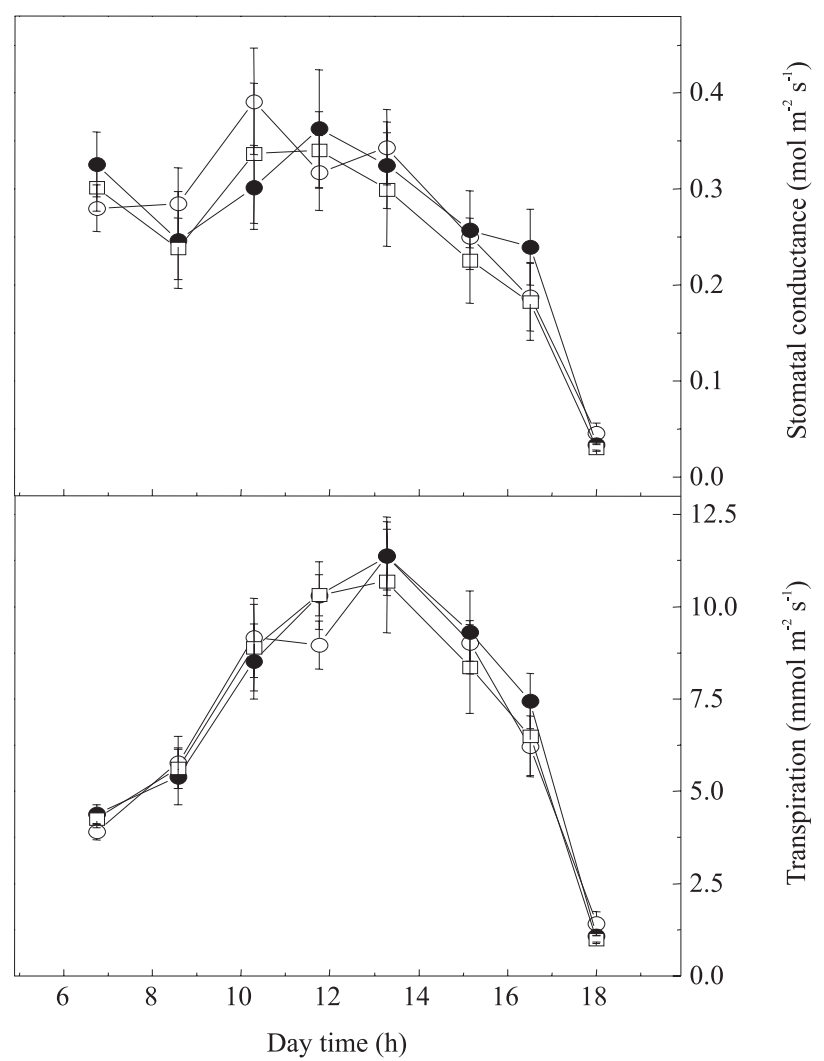

Figure 2. Daily courses of $\mathrm{CO}_{2}$ assimilation, stomatal conductance, intercellular $\mathrm{CO}_{2}$ concentration, and transpiration in bean genotypes 'Carioca' (O), Guarumbé (•), and 'Ouro Negro' $(\square)$ exposed to daily changes of environmental variables in Piracicaba, SP, Brazil. Each point represents the mean \pm standarderror of six replications. 
(ETR) and effective quantum efficiency of PSII ( $\left.\Delta F / F_{m}{ }^{\prime}\right)$, with the highest ETR values coinciding with the highest A values (Figures 2 and 4). According to Maxwell \& Johnson (2000), $\Delta \mathrm{F} / \mathrm{F}_{\mathrm{m}}$ ' is related to the proportion of light absorbed by chlorophyll molecules and used in photochemistry, and its decrease is associated to reaction center closure and thermal energy dissipation processes.

Besides the effects of high irradiance on photosynthesis, plants were also subjected to high air temperature, and this factor is known to cause impairments on photosynthetic apparatus (Berry \& Björkman, 1980). Decrease in $\mathrm{F}_{\mathrm{v}} / \mathrm{F}_{\mathrm{m}}$ with simultaneous increase in $\mathrm{F}_{\mathrm{o}}$ is an indicator of damage in PSII caused by high temperatures (Pastenes \& Horton, 1996a, 1999; Yamane et al., 1997). This pattern was observed in all genotypes, which exhibited the highest $F_{o}$ values at 11:45 am (Figure 5), when air temperature was close to $36^{\circ} \mathrm{C}$ (Figure 1). The $\mathrm{F}_{\mathrm{o}}$ is related to the size of chlorophyll antenna and the rate of thermal deactivation of inhibited PSII centers (Krause \& Weis, 1991). According to Yamane et al. (1997), increase in the $F_{0}$ level is caused partly by reversible inactivation of the PSII reaction center at high temperatures. Moreover, Öquist et al. (1992) have associated increases in $F_{o}$ with protective or regulatory processes that take place at PSII.

Although photochemical reactions had been affected by daily environmental changes (Figures 4 and 5), $\mathrm{CO}_{2}$

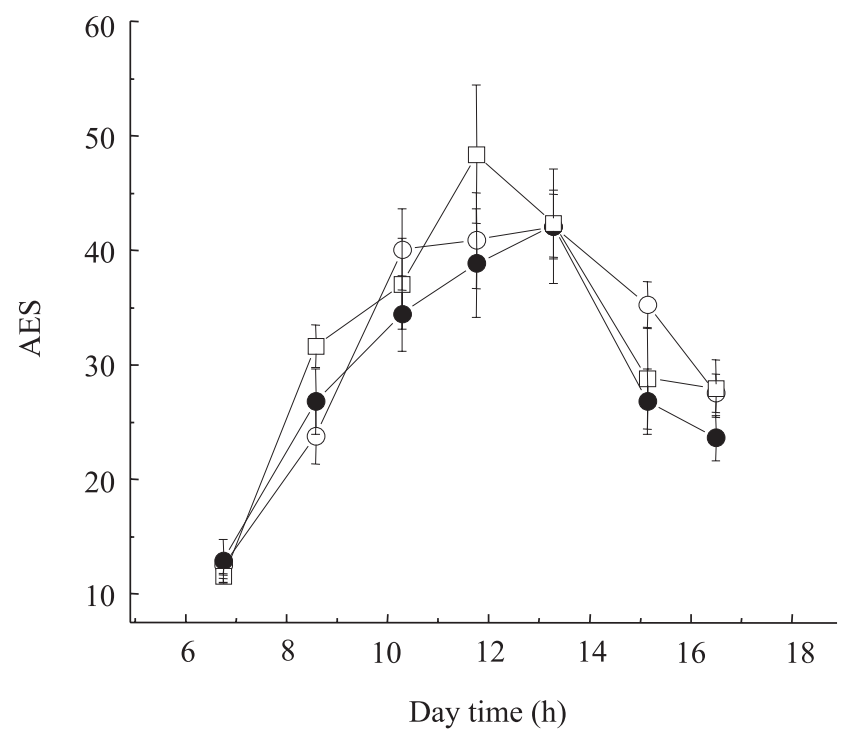

Figure 3. Daily course of alternative electron sink (AES) in bean genotypes 'Carioca' ( $\mathrm{O})$, Guarumbé $(\bullet)$ and 'Ouro Negro' $(\square)$ exposed to daily changes of environmental variables in Piracicaba, SP, Brazil. Each point represents the mean \pm standarderror of six replications. assimilation was not affected by reductions in photochemical activity and genotypes showed similar maximum rates between 8:35 am and 11:45 am (Figure 2). Under controlled condition, bean genotypes exhibited distinct photosynthetic capacities, i.e., maximum photosynthetic rates (Figure 6), which were not observed under natural condition (Figure 2). Photosynthetic capacity (PC) was higher in 'Carioca' ( $\left.35 \mu \mathrm{mol} \mathrm{m} \mathrm{m}^{-2} \mathrm{~s}^{-1}\right)$ than in the other genotypes, exhibiting non-saturation even at 2,000 $\mu \mathrm{mol} \mathrm{m}^{-2} \mathrm{~s}^{-1}$ (Figure 6). 'Ouro Negro' showed PC around $25 \mu \mathrm{mol} \mathrm{m} \mathrm{m}^{-2} \mathrm{~s}^{-1}$ and light saturation at 2,000 $\mu \mathrm{mol} \mathrm{m} \mathrm{m}^{-2} \mathrm{~s}^{-1}$, whereas Guarumbé was not fully saturated and presented $\mathrm{PC}$ around $30 \mu \mathrm{mol} \mathrm{m} \mathrm{m}^{-2} \mathrm{~s}^{-1}$. The maximum $\mathrm{CO}_{2}$ assimilation values observed are in agreement with the measurements performed by Von Caemmerer \& Farquhar (1981), Comstock \& Ehleringer (1993) and Souza et al. (2003) in common bean genotypes. Different photosynthetic capacities between bean cultivars may be caused by differences in carboxylation capacity and protein content (Evans, 1989), as well as by different number of mesophyll cells per unit surface leaf area (Nobel, 1999).

Considering maximal A rates in both experimental conditions, 'Carioca' genotype was more affected by daily changes of environmental variables, showing a reduction of $43 \%$. Guarumbé and 'Ouro Negro' exhibited decreases around $33 \%$ and 20\%, respectively (Figure 6). Stomatal closure could be a cause of PC reduction in 'Carioca' since lower $g_{s}$ values were observed under natural condition. The high $\mathrm{g}_{\mathrm{s}}$ similarity in 'Ouro Negro' and Guarumbé, when considered both experimental conditions, indicated non-stomatal restriction of PC under natural condition.

Besides $g_{s}$ effects (Farquhar \& Sharkey, 1982; Jones, 1998; Nobel, 1999), high temperatures also cause impairments in photochemical and biochemical reactions

Table 1. Leaf water potential (MPa) of bean genotypes 'Carioca', Guarumbé, and 'Ouro Negro' measured at pre-dawn and at $1: 30 \mathrm{pm}$ in plants exposed to full sunlight condition, in Piracicaba, SP, Brazil ${ }^{(1)}$.

\begin{tabular}{lccc}
\hline Day time & \multicolumn{3}{c}{ Bean genotype } \\
\cline { 2 - 4 } & 'Carioca' & Guarumbé & 'Ouro Negro' \\
\hline Pre-dawn & $-0.24 \pm 0.10 \mathrm{aA}$ & $-0.24 \pm 0.03 \mathrm{aA}$ & $-0.23 \pm 0.04 \mathrm{aA}$ \\
$1: 30 \mathrm{pm}$ & $-1.37 \pm 0.14 \mathrm{aB}$ & $-1.37 \pm 0.28 \mathrm{aB}$ & $-1.40 \pm 0.04 \mathrm{aB}$ \\
\hline
\end{tabular}

${ }^{(1)}$ Data represent the mean \pm standart error of 4 replications; different small letters in line and capital letters in column show significant difference by Tukey's test at the 0.05 probability. 


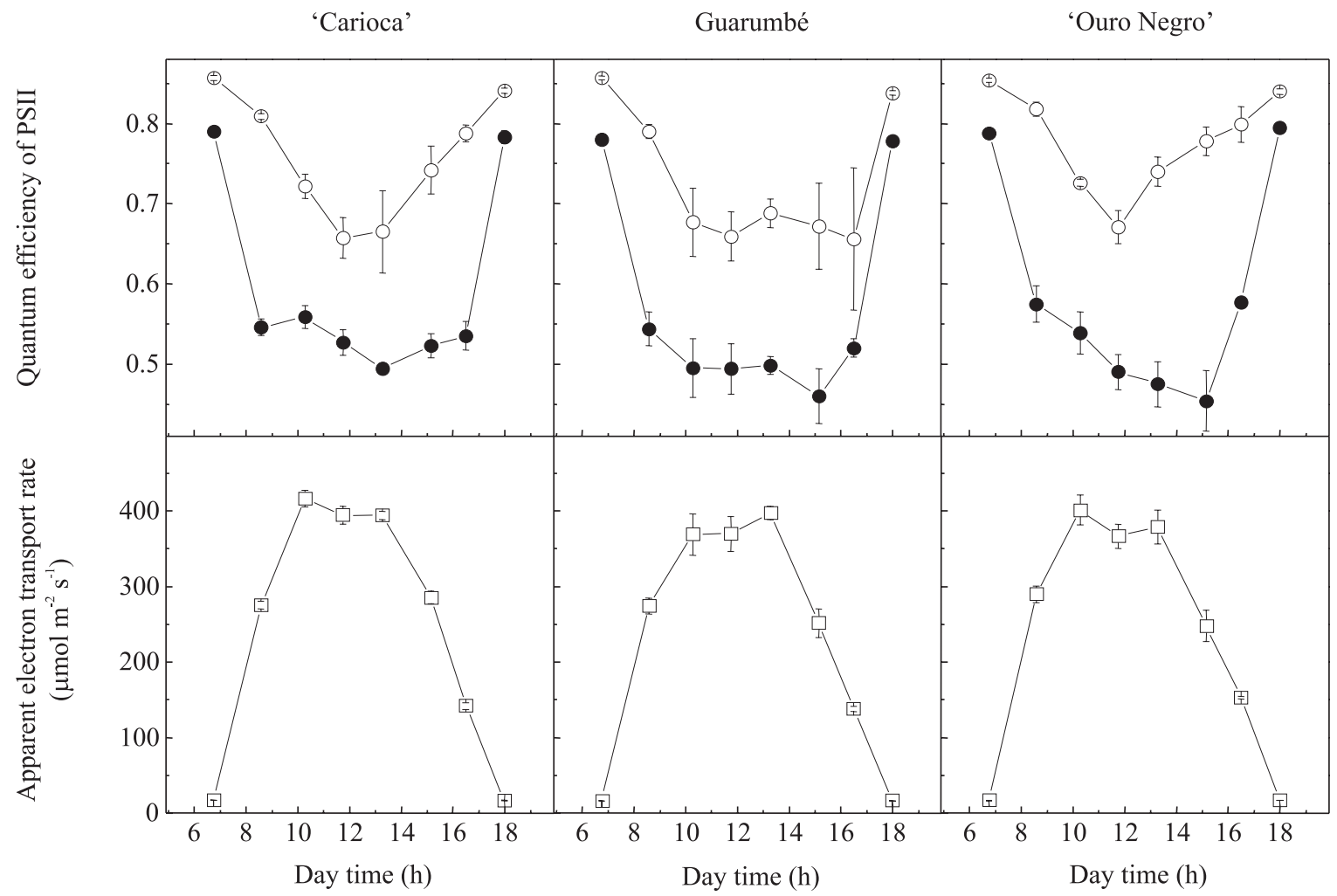

Figure 4. Daily courses of potential (O) and effective $(\bullet)$ quantum efficiency of photosystem II (PSII) and apparent electron transport rate $(\square)$ in bean genotypes 'Carioca', Guarumbé, and 'Ouro Negro' exposed to daily changes of environmental variables in Piracicaba, SP, Brazil. Each point represents the mean \pm standard error of three $(O)$ and six $(\bullet$ and $\square)$ replications.

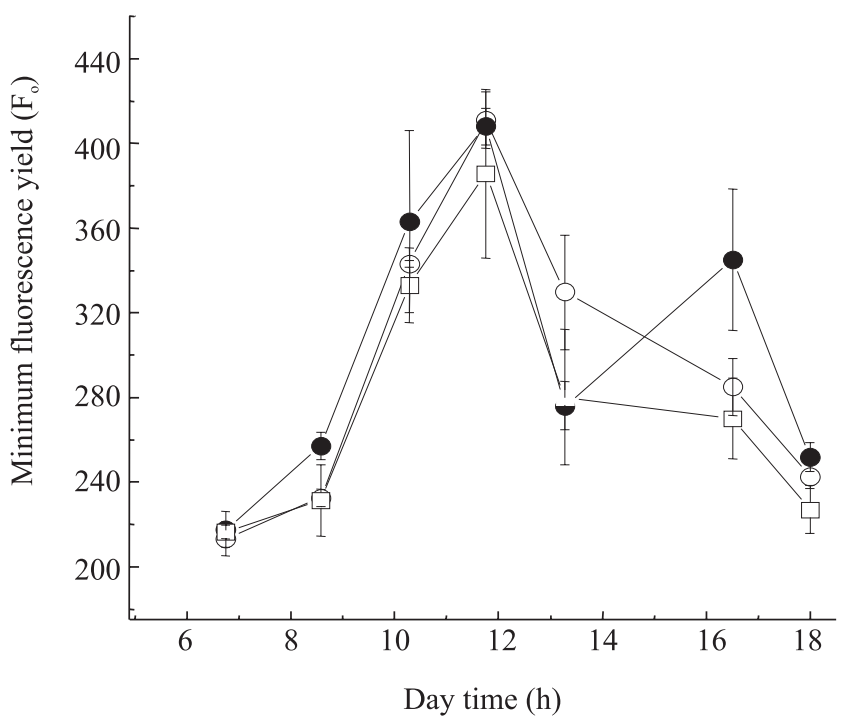

Figure 5. Daily courses of minimum fluorescence yield $\left(\mathrm{F}_{\mathrm{o}}\right)$ in bean genotypes 'Carioca' (O), Guarumbé (๑) and 'Ouro Negro' ( $\square$ ) exposed to daily changes of environmental variables in Piracicaba, SP, Brazil. Each point represents the mean \pm standard error of six replications. of photosynthesis (Berry \& Björkman, 1980; Pastenes \& Horton, 1996a, 1996b, 1999; Costa et al., 2002). Therefore, the results suggest that the PC of 'Carioca' was constrained at natural condition by low $\mathrm{g}_{\mathrm{s}}$ and high temperature, whereas 'Ouro Negro' and Guarumbé had their PC impaired only by high temperature.

All genotypes showed a reversible increase in AES, which was probably caused by increased leaf temperature during daylight period. Among alternative electron sinks, photorespiration is the most important (Cornic \& Fresneau, 2002), acting as a sink for reducing equivalents (e.g. NADPH) and ATP, as well as playing an important role on protection of photosynthetic apparatus from the deleterious effects of excessive light energy (Osmond $\&$ Björkman, 1972). Thus, plant photosynthesis can be decreased by increases in photorespiration under high temperature (Monson et al., 1982; Kobza \& Edwards, 1987). Higher photorespiratory rates could be explained by increase in the $\mathrm{O}_{2} / \mathrm{CO}_{2}$ solubility ratio and in oxygenase activity of Rubisco induced by high 


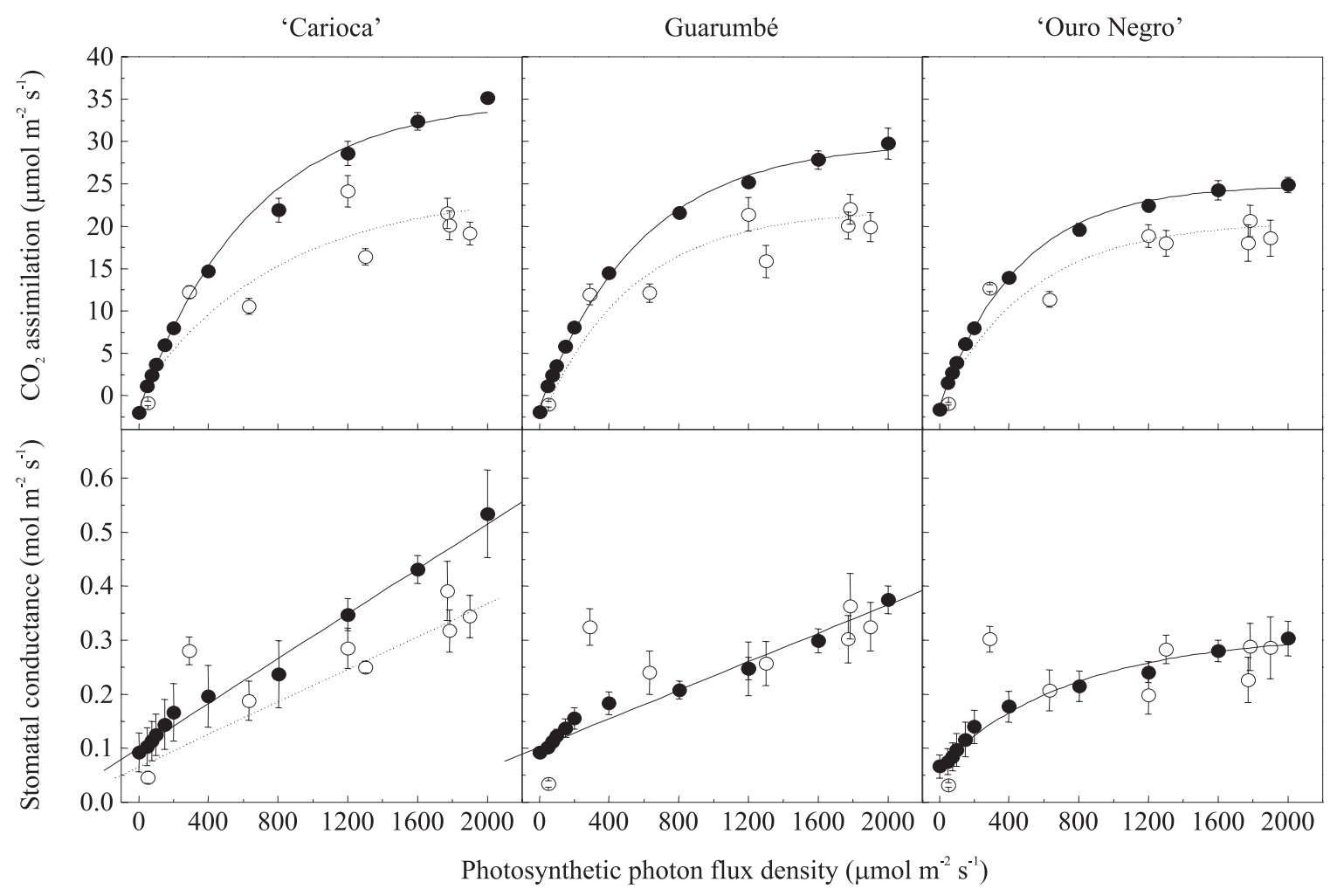

Figure 6. Light response curves of $\mathrm{CO}_{2}$ assimilation and stomatal conductance of bean genotypes 'Carioca', Guarumbé, and 'Ouro Negro' exposed to daily changes of environmental variables in Piracicaba, SP, Brazil (O) and exposed to optimum environmental condition $(\bullet)$. Each point represents the mean \pm standard error value of six $(\mathrm{O})$ and three $(\bullet)$ replications.

temperatures (Ku \& Edwards, 1977; Bernacchi et al., 2001). Therefore, it would be expected negative effects on photosynthesis since $\mathrm{T}_{\text {leaf }}$ was higher than $36^{\circ} \mathrm{C}$ in the afternoon and the optimum temperature for bean growth and photosynthesis is around $25^{\circ} \mathrm{C}$ (Jones, 1971 ; Singh, 1989).

Results indicated that the photosynthetic capacity of 'Carioca' was reduced by low $\mathrm{g}_{\mathrm{s}}$ values and increased AES under natural condition, whereas 'Ouro Negro' and Guarumbé were affected only by increased AES (Figures 3 and 6). Higher susceptibility of the genotype ' $\mathrm{Ca}$ rioca' to high $\mathrm{VPD}_{\text {leaf-air }}$ and temperature (low $\mathrm{g}_{\mathrm{s}}$ and high AES, respectively) is in agreement with previous reports that indicated 'Carioca' as an improper genotype for regions with high $\mathrm{T}_{\text {air }}$ and VPD (Masaya \& White, 1991; Costa et al., 2002). However, this genotype may be very useful in breeding programs for increase photosynthetic capacity, since the highest $\mathrm{CO}_{2}$ assimilation values were observed in 'Carioca' under optimum environmental condition.

\section{Conclusion}

1. When compared with 'Ouro Negro' and Guarumbé, 'Carioca' exhibits the highest photosynthetic capacity under optimum environmental condition.

2. 'Carioca' photosynthetic rate is more affected by daily changes of air temperature and leaf-to-air vapor pressure difference.

\section{Acknowledgements}

To Fapesp (Fundação de Amparo à Pesquisa do Estado de São Paulo, Brazil), Capes (Coordenação de Aperfeiçoamento de Pessoal de Nível Superior, Brazil), and to $\mathrm{CNPq}$ (Conselho Nacional de Desenvolvimento Científico e Tecnológico, Brazil), for fellowships granted.

\section{References}

BERRY, J.; BJÖRKMAN, O. Photosynthetic response and adaptation to temperature in higher plants. Annual Review of Plant Physiology, v.31, p.491-543, 1980. 
BERNACCHI, C.J.; SINGAAS, E.L.; PIMENTEL, C.; PORTIS JUNIOR, A.R.; LONG, S.P. Improved temperature response functions for models of Rubisco-limited photosynthesis. Plant, Cell and Environment, v.24, p.253-259, 2001.

CHAMPIGNEY, M.L. Integration of photosynthetic carbon and nitrogen metabolism in higher plants. Photosynthesis Research, v.46, p.117-127, 1995.

COMSTOCK, J.; EHLERINGER, J. Stomatal response to humidity in common bean (Phaseolus vulgaris L.): implications for maximum transpiration rate, water-use efficiency and productivity. Australian Journal of Plant Physiology, v.20, p.669-691, 1993.

CORNIC, G.; FRESNEAU, C. Photosynthetic carbon reduction and carbon oxidation cycles are the main electron sinks for photosystem II activity during a mild drought. Annals of Botany, v.89, p.887-894, 2002. Special issue.

COSTA, E.S.; BRESSAN-SMITH, R.; OLIVEIRA, J.G.; CAMPOSTRINI, E.; PIMENTEL, C. Photochemical efficiency in bean plants (Phaseolus vulgaris L. and Vigna unguiculata L. Walp) during recovery from high temperature stress. Brazilian Journal of Plant Physiology, v.14, p.105-110, 2002.

CRITCHLEY, C. Photoinhibition. In: RAGUAVENDRA, A.S. (Ed.). Photosynthesis: a comprehensive treatise. Cambridge, England: Cambridge University Press, 1998. p.264-272.

DEMMIG, B.; BJÖRKMAN, O. Comparison of the effects of excessive light on chlorophyll fluorescence $(77 \mathrm{~K})$ and photon yield of $\mathrm{O}_{2}$ evolution in leaves of higher plants. Planta, v.171, p.171-184, 1987.

DEMMIG-ADAMS, B.; ADAMS III, W.W. Photoprotection and other responses of plants to high light stress. Annual Review of Plant Physiology and Plant Molecular Biology, v.43, p.599-626, 1992.

DOURADO NETO, D.; FANCELLI, A.L. Produção de feijão. Guaíba: Agropecuária, 2000. 386p.

EDWARDS, G.E.; BAKER, N.R. Can carbon dioxide assimilation in maize leaves be predicted accurately from chlorophyll fluorescence analysis? Photosynthesis Research, v.37, p.89-102, 1993.

EVANS, J.R. Photosynthesis and nitrogen relationships in leaves of $\mathrm{C}_{3}$ plants. Oecologia, v.78, p.9-19, 1989.

FARQUHAR, G.D.; SHARKEY, T.D. Stomatal conductance and photosynthesis. Annual Review of Plant Physiology, v.33, p.317345, 1982.

JONES, L.H. Adaptive responses to temperature in dwarf French beans, Phaseolus vulgaris L. Annals of Botany, v.35, p.581-596, 1971.

JONES, H.G. Stomatal control of photosynthesis and transpiration. Journal of Experimental Botany, v.49, p.387-398, 1998. Special issue.

KOBZA, J.; EDWARDS, G.E. Influences of leaf temperature on photosynthetic carbon metabolism in wheat. Plant Physiology, v.83, p.69-74, 1987.

KRAUSE, G.H.; WEIS, E. Chlorophyll fluorescence and photosynthesis: the basics. Annual Review of Plant Physiology and Plant Molecular Biology, v.42, p.313-349, 1991.
KU, S.B.; EDWARDS, G.E. Oxygen inhibition of photosynthesis I: temperature dependence and relation to $\mathrm{O}_{2} / \mathrm{CO}_{2}$ solubility ratio. Plant Physiology, v.59, p.986-990, 1977.

LONG, S.P.; HUMPHRIES, S.; FALKOWSKI, P.G. Photoinhibition of photosynthesis in nature. Annual Review of Plant Physiology and Plant Molecular Biology, v.45, p.633-662, 1994.

LOPES, N.F.; OLIVA, M.A.; CARDOSO, M.J.; GOMES, M.M.S.; SOUZA, V.F.D. Crescimento e conversão da energia solar em Phaseolus vulgaris L. submetido a três densidades de fluxo radiante e dois regimes hídricos. Revista Ceres, v.33, p.142-164, 1986.

MASAYA, P.; WHITE, J.W. Adaptation to photoperiod and temperature. In: SCHOONHOVEN, A. van; VOYSEST, O. (Ed.). Common beans: research for crop improvement. Cali: Centro Internacional de Agricultura Tropical, 1991. p.445-500.

MAXWELL, K.; JOHNSON, G.N. Chlorophyll fluorescence: a practical guide. Journal of Experimental Botany, v.51, p.659$668,2000$.

McCREE, K.J. Measuring the whole-plant daily carbon balance. Photosynthetica, v.20, p.82-93, 1986.

MONSON, R.K.; STIDHAM, M.A.; WILLIAMS III, G.J.; EDWARDS, G.E.; URIBE, E.G. Temperature dependence of photosynthesis in Agropyron smithii Rybd. - I: factors affecting net $\mathrm{CO}_{2}$ uptake in intact leaves and contribution from ribulose-1,5bisphosphate carboxylase measured in vivo and in vitro. Plant Physiology, v.69, p.921-928, 1982.

NOCTOR, G.; VELJOVIC-JOVANOVIC, S.; DRISCOLL, S.; NOVITSKAYA, L.; FOYER, C.H. Drought and oxidative load in the leaves of $\mathrm{C}_{3}$ plants: a predominant role for photorespiration. Annals of Botany, v.89, p.841-850, 2002. Special issue.

NOBEL, P.S. Physicochemical and environmental plant physiology. New York: Academic, 1999. 474p.

ÖQUIST, G.; CHOW, W.S.; ANDERSON, J.M. Photoinhibition of photosynthesis represents a mechanism for the long term regulation of photosystem II. Planta, v.186, p.450-460, 1992.

OSMOND, C.B. What is photoinhibition? Some insights from comparisons of shade and sun plants. In: BAKER, N.R.; BOWYER, J.R. (Ed.). Photoinhibition of photosynthesis: from molecular mechanisms to the field. Oxford: Bios Scientific, 1994. p.1-24.

OSMOND, C.B.; BJÖRKMAN, O. Simultaneous measurement of $\mathrm{O}_{2}$ effects on net photosynthesis and glycolate metabolism in $\mathrm{C}_{3}$ and $\mathrm{C}_{4}$ species of Atriplex. Annual Report of the Director Department of Plant Biology, v.71, p.141-148, 1972.

PASTENES, C.; HORTON, P. Effect of high temperature on photosynthesis in beans - I: oxygen evolution and chlorophyll fluorescence. Plant Physiology, v.112, p.1245-1251, 1996a.

PASTENES, C.; HORTON, P. Effect of high temperature on photosynthesis in beans - II: $\mathrm{CO}_{2}$ assimilation and metabolite contents. Plant Physiology, v.112, p.1253-1260, 1996b.

PASTENES, C.; HORTON, P. Resistance of photosynthesis to high temperature in two bean varieties. Photosynthesis Research, v.62, p.197-203, 1999.

PIMENTEL, C.; HERBERT, G.; SILVA, J.V. da. Effects of drought on $\mathrm{O}_{2}$ evolution and stomatal conductance of beans at pollination stage. Environmental and Experimental Botany, v.42, p.155-162, 1999a. 
PIMENTEL, C.; LAFFRAY, D.; LOUGUET, P. Intrinsic water use efficiency at the pollination stage as a parameter for drought tolerance selection in Phaseolus vulgaris L. Physiologia Plantarum, v.106, p.184-198, 1999b.

SCHREIBER, U.; BILGER, W.; NEUBAUER, C. Chlorophyll fluorescence as a non-intrusive indicator for rapid assessment of in vivo photosynthesis. In: SCHULZE, E.D.; CALDWELL, M.M. (Ed.). Ecophysiology of photosynthesis. Berlin: Springer, 1994. p.4970. (Ecological Studies, 100).

SINGH, S.P. Patterns of variation in cultivated common bean (Phaseolus vulgaris, Fabaceae). Economic Botany, v.43, p.39-57, 1989.
SOUZA, G.M.; GIAVENO, C.D.; AIDAR, S.T.; OLIVEIRA, R.F. Drought stability in different common bean genotypes. Crop Breeding and Applied Biotechnology, v.3, p.203-208, 2003.

VAN KOOTEN, O.; SNEL, J.F.H. The use of chlorophyll fluorescence nomenclature in plant stress physiology. Photosynthesis Research, v.25, p.147-150, 1990.

VON CAEMMERER, S.; FARQUHAR, G.D. Some relationships between the biochemistry of photosynthesis and the gas exchange of leaves. Planta, v.153, p.376-387, 1981.

YAMANE, Y.; KASHINO, Y.; KOIKE, H.; SATOH, K. Increases in the fluorescence $F_{0}$ level and reversible inhibition of photosystem II reaction center by high-temperature treatments in higher plants. Photosynthesis Research, v.52, p.57-64, 1997.

Received on October 20, 2003 and accepted on April 26, 2004 